\title{
ANALISIS POTENSI DAN KONDISI EKOSISTEM TERUMBU KARANG PULAU MENJANGAN UNTUK PENGEMBANGAN EKOWISATA BAHARI BERBASIS PENDIDIKAN TERPADU
}

\author{
P. Budi Adnyana ${ }^{1}$, G. Ari Yudasmara ${ }^{2}$, G. Budasi ${ }^{3}$ \\ ${ }^{1}$ Jurusan Pendidikan Biologi, ${ }^{2}$ Jurusan Budidaya Kelautan, ${ }^{3}$ Jurusan Pendidikan \\ Bahasa Inggris, Universitas Pendidikan Ganesha, \\ Singaraja Indonesia \\ e-mail : profbudiadnyana@gmail.com
}

\begin{abstract}
Abstrak
Penelitian ini bertujuan untuk 1) menganalisis potensi dan kondisi perairan Pulau Menjangan, 2) menganalisis kesesuaian pemanfaatan ekowisata bahari, dan 3) menganalisis daya dukung ekologi untuk ekowisata bahari. Metode pengumpulan data menggunakan metode sampling dengan manta tow, line intercept transect dengan bantuan alat water quality checker, floater current meter, tide gaugh. Data dianalisis secara deskriptif. Berdasarkan hasil analisis data penelitian dapat dibuat beberapa kesimpulan seperti berikut: 1) Perairan Pulau Menjangan memiliki kondisi yang baik untuk dikembangkan menjadi destinasi ekowisata bahari karena memiliki ekosistem trumbu karangan yang sangat indah dengan adanya beragam ikan karang dan biota lainnya; 2) Kondisi biofisik perairan Pulau Menjangan memenuhi syarat untuk dapat kegiatan diving dan snorkeling; 3) Daya dukung kawasan Pulau Menjangan yang dapat dimanfaatkan untuk kegiatan diving adalah 28 orang per hari dan untuk snorkling 24 orang per hari, 4) Untuk keberlajutan kegiatan ekowisata bahari di Pulau Menjangan dapat dikembangkan suatu Model Ekowisata Bahari Berbasis Pendidikan Terpadu (EBBPT), melalui edukasi tentang pentingnya konservasi yang perlu diberikan kepada seluruh yang terlibat dalam pariwisata dan dapat dikembangkan atraksi wisata edukatif seperti mengidentifikasi terumbu karang dan atraksi wisata konservasi dengan melakukan trasplantasi karang. Oleh karena itu dalam mendukung aktivitas wisata edukatif pada ekowisata bahari perlu dikembangkan buklet panduan identifikasi trumbu karang dan buklet untuk wisata konservasi untuk melakukan transplantasi terumbu karang.
\end{abstract}

Kata kunci: kondisi, potensi, terumbu karang, ekowisata bahari

\begin{abstract}
This study aimed to 1) analyze the potential and conditions for Menjangan Island waters, 2) analyze the suitability of the use of marine ecotourism, and 3) analyze the ecological carrying capacity for marine ecotourism. Methods of data collection using the manta tow sampling, line intercept transect with the aid of a water quality checker, floater current meter, tide Gaugh. Data were analyzed descriptively. Based on the analysis of research data some conclusions can be made as follows: 1) Menjangan coastal have good conditions to develop a marine ecotourism destination because it has a bouquet of coral ecosystems are extremely beautiful with a variety of reef fish and other biota, 2) Condition biophysical Island waters Menjangan be eligible for diving and snorkeling activities,
\end{abstract}


3) carrying capacity Menjangan Island area that can be used for diving activities is 28 people per day and for snorkeling 24 people per day 4) to Sustainability Menjangan marine ecotourism can be developed a Marine Ecotourism ModelBased Integrated Education (MEMBIE). Education about the importance of conservation should be given to all involved in the development of tourism and tourist attractions such as identifying coral reef educational and tourist attraction by doing transplantation reef conservation; to support educational travel activities on marine eco-tourism should be developed reef coral identification guide booklets and booklet for conservation advice for transplanting coral reefs.

Key words: condition, potency, coral reef, marine ecotourism

\section{PENDAHULUAN}

Kawasan Pulau Menjangan
merupakan salah satu destinasi
ekowisata bahari yang berada di kawasan Taman Nasional Bali Barat (TNBB). Secara geografis terletak pada posisi antara 114ำ12'02" - 114ำ14'30" Bujur Timur dan 805'20"- 817'20" Lintang Selatan. Keindahan bawah laut Pulau Menjangan sudah sangat terkenal sehingga banyak wisatawan lokal atau internasional datang ke pulau ini.

Wisatawan yang datang ke kawasan Pulau Menjangan kebanyakan hanya untuk melihat keindahan alam bawah laut dan melakukan aktivitas seperti memasuki wisata bahari (bukan ekowisata bahari). Aktivitas wisatawan di kawasan ekowisata harus dapat menjaga kelestraian lingkungan dan dapat meningkatkan ekonomi masyarakat lokal. Hal ini sesuai dengan The International Ecotourism Society yang mendefinisikan ekotorisme sebagai "responsible travel to natural areas that conserves the environment and sustains the well being of local people." Berdasarkan definisi ini berarti "Ekowisata adalah perjalanan yang bertanggung jawab ketempat-tempat yang alami dengan menjaga kelestarian lingkungan dan meningkatkan kesejahtraan penduduk setempat".
Wood (2002) menguraikan bahwa komponen ekowisata adalah sebagai berikut: (1) dapat memberi sumbangan pada konservasi biodiversitas; (2) dapat menopang kesejahteraan masyarakat lokal; (3) mengamalkan pengalamanpengalaman (yang diperoleh dalam ekowisata pada kehidupan kesehariannya); (4) melibatkan tanggungjawab wisatawan dan industri pariwisata (pada lingkungan dan budaya lokal yang ada); (5) Dilakukan oleh sekelompok kecil wisatawan oleh pebisnis yang juga berskala kecil; (6) mewajibkan konsumsi yang rendah dari sumber daya yang tidak dapat diperbaharui (dalam perjalanan ekowisata); (7) menekankan pada partisipasi lokal, baik kepemilikan maupun kesempatan berusaha, terutama masyarakat di sekitar areal lokasi ekowisata.

Untuk meningkatkan pemahaman dan apresiasi terhadap lingkungan dan menjaga keberlajutan ekowisata bahari di kawasan Pulau Menjangan dapat dilakukan dengan mengedukasi wisatawan dan melibatkannya dalam usaha konservasi sehingga dapat. Hal ini dapat dilakukan dengan mengembangkan ekowisata bahari berbasis pendidikan terpadu. Dengan demikian, perlu melakukan penelitian 
mengenai potensi dan kondisi terumbu karang Pulau Menjangan. Tujuan penelitian adalah untuk: 1) menganalisis potensi dan kondisi perairan Pulau Menjangan, 2) menganalisis kesesuaian pemanfaatan ekowisata bahari, dan 3) menganalisis daya dukung ekologi untuk pemanfaatan ekowisata bahari.

\section{METODE}

\section{Lokasi dan Waktu Penelitian}

Penelitian ini dilaksanakan di perairan Pulau Menjangan yang terletak di area Taman Nasional Bali Barat, Kecamatan Gerokgak, Kabupaten Buleleng, Provinsi Bali. Secara geografis terletak pada posisi antara 11412'02"- 114ำ14'30" Bujur Timur dan 805'20"- 817'20" Lintang Selatan. Lokasi ini dipilih karena Pulau Menjangan merupakan salah satu destinasi ekowisata bahari yang perlu dikembangkan agar menjadi destinasi yang berkelanjutan. Waktu penelitian bulan Agustus sampai dengan Oktober 2012. Peta lokasi penelitian dapat dilihat pada Gambar 1. Penelitian dilakukan dalam 6 lokasi atau stasiun.

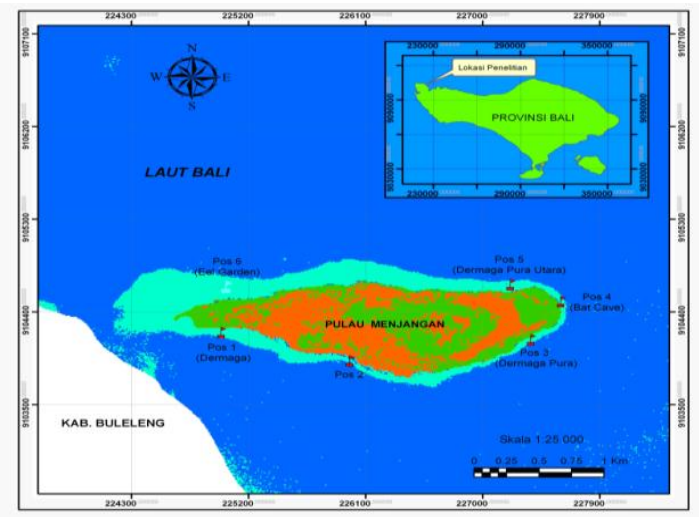

Gambar 1 Peta Pulau Menjangan

\section{Metode Pengumpulan Data}

Data yang dikumpulkan dalam penelitian Tahun I adalah: 1) Data kondisi ekosistem yang meliputi: kecerahan perairan, jenis life form, lebar hamparan datar karang, kedalaman terumbu karang, dan kecepatan arus, dan 2) Data kondisi kualitas perairan Pulau Menjangan yang meliputi data temperature air laut, turbiditas, $\mathrm{pH}$ air laut, Salinitas, DO, $\mathrm{BOD}_{5}, \mathrm{NH}_{3}$.

\section{Metode Analisis Data \\ a. Analisis Data Kondisi Ekosistem}

Kondisi ekosistem dianalisis secara deskriptif dengan menguraikan secara naratif tentang persentase tutupan karang dan jenis ikan yang ada dan keadaan arusnya. Persentase tutupan adalah persentase luas area yang ditutupi oleh pertumbuhan karang. Persentase karang hidup yang tinggi menandakan bahwa terumbu karang di suatu perairan berada dalam keadaan sehat. Formula yang digunakan untuk menghitung tutupan karang mengacu rumus menurut English et al. (1994), yaitu :

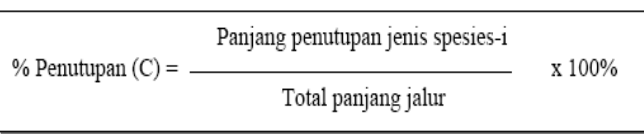

Katagori persentase tutupan mengacu pada katagori dari Bachtiar (2001) yaitu

(1) Sangat Jelek : $0-10 \%$

(2) Jelek : :11-30\%

(3) Sedang : : $31-50 \%$

(4) Baik : $51-75 \%$

(5) Sangat Baik : : $76-100 \%$

\section{b. Analisis Kualitas Perairan}

Analisis kualias perairan dianalisis secara deskriptif berdasarkan data hasil 
penelitian mengenai temperatur perairan, tubiditas, $\mathrm{pH}$, Salinitas, DO, BOD, dan $\mathrm{NH}_{3}$. Kriteria penilaian kualitas perairan yang cocok untuk kegiatan ekowisata bahari mengacu pada Kepmen Negara LH No. 51 Tahun 2004

\section{c. Analisis Kesesuaian Pemanfaatan}

Analisis kesesuaian pemanfaatan adalah analisis potensi sumber daya dan lingkungannya untuk dikembangkan sebagai obyek ekowisata bahari. Rumus yang digunakan untuk menganalisis kesesuaian ekowisata bahari ini mengacu pada Hutabarat et al. (2009) sebagai berikut.

$\mathrm{IK} \mathrm{W}=[\Sigma \mathrm{Ni} / \mathrm{Nmaks}] \times 100$

Tabel 2. Kesesuaian Untuk Ekowisata Diving

\begin{tabular}{|c|c|c|c|c|}
\hline No & Parameter & Bobot & Standar Parameter & Skor \\
\hline 1 & Tutupan karang hidup (\%) & 3 & $\begin{aligned} & >75 \\
> & 50-75 \\
& 25-50 \\
& <25\end{aligned}$ & $\begin{array}{l}3 \\
2 \\
1 \\
0\end{array}$ \\
\hline 2 & Kecerahan perairan (\%) & 3 & $\begin{array}{c}100 \\
80-<100 \\
20-<50 \\
<20\end{array}$ & $\begin{array}{l}3 \\
2 \\
1 \\
0\end{array}$ \\
\hline 3 & Jumlah jenis life form & 2 & $\begin{array}{c}>12 \\
<7-12 \\
4-7 \\
<4\end{array}$ & $\begin{array}{l}3 \\
2 \\
1 \\
0\end{array}$ \\
\hline 4 & Jumlah jenis ikan karang & 2 & $\begin{array}{c}>100 \\
50-100 \\
20-<50 \\
<20\end{array}$ & $\begin{array}{l}3 \\
2 \\
1 \\
0\end{array}$ \\
\hline 5 & $\begin{array}{ll}\text { Kedalaman } & \text { terumbu } \\
\text { karang }(m) & \end{array}$ & 2 & $\begin{array}{c}6-15 \\
>15-20 \text { atau } 3-5 \\
>20-30 \\
>30 \text { atau }<3\end{array}$ & $\begin{array}{l}3 \\
2 \\
1 \\
0\end{array}$ \\
\hline
\end{tabular}

dimana :

IKW = indeks kesesuaian wisata

$\mathrm{Ni}=$ nilai parameter ke-i (bobot $\mathrm{x}$ skor) Nmaks = nilai maksimum dari suatu kategori wisata

Penentuan kesesuaian, diperoleh melalui bantuan matriks kesesuaian yang disusun berdasarkan acuan kriteria kesesuaian setiap peruntukkan. Kesesuaian kawasan dilihat dari tingkat persentase kesesuaian yang diperoleh melalui penjumlahan nilai dari seluruh parameter. Matriks kesesuaian wisata tersebut secara lengkap dapat dilihat pada Tabel 4, Tabel 2 dan Tabel 3 


\begin{tabular}{|c|c|c|c|c|}
\hline & & $0-15$ & 3 \\
6 & Kecepatan arus (cm/det) & 1 & $>15-30$ & 2 \\
& & $>30-50$ & 1 \\
& & $>50$ & 0 \\
\hline
\end{tabular}
(2004); DKP (2003); Hutabarat et al. (2009)

Keterangan:

Nilai maksimum $=39$

$\mathrm{S} 1$ = Sangat sesuai, dengan nilai IKW $80-100$

S2 = Cukup sesuai, dengan nilai IKW 60 $-<80$
S3 = Sesuai bersyarat, dengan nilai IKW $45-<60$

S4 = Tidak sesuai, dengan nilai IKW < 45

Tabel 3. Kesesuaian Untuk Ekowisata Snorkeling

\begin{tabular}{|c|c|c|c|c|}
\hline No & Parameter & Bobot & $\begin{array}{c}\text { Standar } \\
\text { Parameter }\end{array}$ & Skor \\
\hline 1 & Tutupan karang hidup (\%) & 3 & $\begin{array}{c}>75 \\
>50-75 \\
25-50 \\
\\
<25\end{array}$ & $\begin{array}{l}3 \\
2 \\
1 \\
0\end{array}$ \\
\hline 2 & Kecerahan perairan (\%) & 3 & $\begin{array}{c}100 \\
80-<100 \\
20-<50 \\
<20\end{array}$ & $\begin{array}{l}3 \\
2 \\
1 \\
0\end{array}$ \\
\hline 3 & Jumlah jenis life form & 2 & $\begin{array}{c}>12 \\
<7-12 \\
4-7 \\
<4\end{array}$ & $\begin{array}{l}3 \\
2 \\
1 \\
0\end{array}$ \\
\hline 4 & Jumlah jenis ikan karang & 2 & $\begin{array}{c}>50 \\
30-50 \\
10-<30 \\
<10\end{array}$ & $\begin{array}{l}3 \\
2 \\
1 \\
0\end{array}$ \\
\hline 5 & Kedalaman terumbu karang (m) & 2 & $\begin{array}{c}1-3 \\
>3-6 \\
>6-10 \\
>10 \text { atau }<1\end{array}$ & $\begin{array}{l}3 \\
2 \\
1 \\
0\end{array}$ \\
\hline 6 & $\begin{array}{l}\text { Lebar hamparan datar karang } \\
(\mathrm{m})\end{array}$ & 2 & $\begin{array}{c}>500 \\
>100-500 \\
20-100 \\
<20\end{array}$ & $\begin{array}{l}3 \\
2 \\
1 \\
0\end{array}$ \\
\hline
\end{tabular}




\begin{tabular}{|c|l|c|c|c|}
\hline 7 & Kecepatan arus (cm/det) & & $0-15$ & 3 \\
& & 1 & $>15-30$ & 2 \\
& & & $>30-50$ & 1 \\
\hline
\end{tabular}

Sumber: Davis dan Tisdell (1995); Davis dan Tisdell (1996); deVantier dan Turak (2004); DKP (2003); Hutabarat et al. (2009)

Keterangan:

Nilai maksimum $=45$

$\mathrm{S} 1$ = Sangat sesuai, dengan nilai IKW $80-100$

S2 = Cukup sesuai, dengan nilai IKW 60 $-<80$

S3 = Sesuai bersyarat, dengan nilai IKW $45-<60$

S4 = Tidak sesuai, dengan nilai $\mathrm{IKW}<$ 45

\section{d. Daya Dukung Ekologi Ekowisata Bahari}

Analisis daya dukung ekologi dimaksudkan untuk menganalisis tingkat maksimum penggunaan suatu ekosistem, berupa jumlah atau kegiatan yang diakomodasikan di dalamnya, sebelum terjadi suatu penurunan kualitas ekologis. Daya dukung ekologi yang digunakan dengan pendekatan daya dukung kawasan (DDK), yaitu: jumlah maksimum pengunjung secara fisik dapat ditampung di kawasan yang disediakan pada waktu tertentu tanpa menimbulkan gangguan pada alam dan manusia. Perhitungan untuk analisis daya dukung kawasan ini, mengacu rumus Hutabarat et al. (2009) sebagai berikut:

$$
\mathrm{DDK}=\mathrm{K} \times \mathrm{Lp} / \mathrm{Lt} \times \mathrm{Wt} / \mathrm{Wp}
$$

dimana :
DDK = daya dukung kawasan (orang),

$\mathrm{K}=$ kapasitas pengunjung per satuan unit area (orang),

$\mathrm{Lp}=$ luas area yang dapat dimanfaatkan $\left(\mathrm{m}^{2}\right)$,

Lt = unit area untuk kategori tertentu $\left(\mathrm{m}\right.$ dan $\mathrm{m}^{2}$ ),

$\mathrm{Wt}=$ waktu yang disediakan oleh kawasan untuk kegiatan wisata dalam 1 hari (jam),

$\mathrm{Wp}=$ waktu yang dihabiskan oleh pengunjung untuk setiap kegiatan (jam).

Kapasitas pengunjung ditentukan oleh kondisi sumber daya dan jenis kegiatan yang akan dikembangkan. Luas suatu area yang dapat digunakan oleh pengunjung mempertimbangkan kemampuan alam mentolerir pengunjung sehingga keasliannya terjaga. Setiap melakukan kegiatan ekowisata, setiap pengunjung akan memerlukan ruang gerak yang cukup luas untuk melakukan aktivitas wisata, sehingga perlu adanya prediksi waktu yang dibutuhkan untuk setiap kegiatan wisata. Nilai maksimum (K) per satuan unit area dan (Lt) untuk setiap kategori wisata bahari serta waktu yang dibutuhkan untuk setiap kegiatan wisata Tabel 4 dan Tabel 5. 
Tabel 4. Kapasitas Pengunjung (K) dan Luas Area Kegiatan (Lt)

\begin{tabular}{|c|c|c|c|}
\hline $\begin{array}{c}\text { Jenis } \\
\text { Kegiatan }\end{array}$ & $\begin{array}{c}\mathrm{K} \\
(\Sigma \text { pengunjung })\end{array}$ & $\begin{array}{c}\text { Unit Area } \\
(\mathrm{Lt})\end{array}$ & Ket \\
\hline Selam & 2 & $1000 \mathrm{~m}^{2}$ & $\begin{array}{c}\text { Setiap 2 orang dalam 100 x 10 m } \\
\text { Setiap 1 orang dalam 50 } 5 \mathrm{~m}\end{array}$ \\
Snorkeling & 1 & $250 \mathrm{~m}^{2}$ & \\
\hline
\end{tabular}

Sumber: Hutabarat et al. (2009)

Tabel 5. Waktu yang Dibutuhkan untuk Setiap Kegiatan Wisata

\begin{tabular}{|c|c|c|}
\hline Kegiatan & $\begin{array}{c}\text { Waktu yang } \\
\text { dibutuhkan Wp-(jam) }\end{array}$ & Total waktu 1 hari Wt-(jam) \\
\hline Selam & 2 & 8 \\
Snorkeling & 3 & 6 \\
\hline
\end{tabular}

Sumber: Hutabarat et al. (2009)

Karena adanya ketentuan PP No. 18 tahun 1994 tentang pengusahaan pariwisata alam di zona pemanfaatan taman nasional dan taman wisata alam yaitu $10 \%$ dari luas zona pemanfaatan maka formulasi daya dukung kawasan untuk pemanfaatan ekowisata dibatasi dengan rumus:

$\mathrm{DDW}=0.1 \times \mathrm{DKK}$

dimana :

DDW = daya dukung wisata (orang);

DDK = daya dukung kawasan (orang)
HASIL DAN PEMBAHASAN

\section{Potensi dan Kondisi Perairan Pulau Menjangan}

\section{a. Ekosistem Terumbu Karang}

Hasil pengamatan pada 6 stasiun (ST) menunjukkan bahwa kontur karang memiliki bentuk yang yang merupakan perpaduan antara berbentuk datar (flat) ke kontur yang terjal atau disebut "drop off". Pengamatan pada kedalam 3 meter dan 10 meter diperoleh data seperti Tabel 6 dan Tabel 7.

Tabel 6 Tutupan Karang di Pulau Menjangan pada Kedalaman 3 meter (dalam \%)

\begin{tabular}{|c|c|c|c|c|c|c|}
\hline & ST1 & ST2 & ST3 & ST4 & ST5 & ST6 \\
\hline Acropora & 17,0 & 18,7 & 26,6 & 31,0 & 11,50 & 29,6 \\
\hline Non Acropora & 14,2 & 24,4 & 30,0 & 29,6 & 25,10 & 33,3 \\
\hline Biota lain & 11,3 & 29,0 & 13,0 & 22,2 & 19,10 & 12,6 \\
\hline Abiotik & 10,5 & 25,0 & 20,2 & 04,1 & 17,10 & 20,9 \\
\hline Dead Coral & 27,0 & 13,0 & 10,0 & 03,0 & 27,00 & 05,0 \\
\hline
\end{tabular}


Tabel 7 Tutupan Karang di Pulau Menjangan pada Kedalaman Kedalaman 10 meter (dalam \%)

\begin{tabular}{|c|c|c|c|c|c|c|}
\hline & ST1 & ST2 & ST3 & ST4 & ST5 & ST6 \\
\hline Acropora & 20,4 & 11,8 & 25,0 & 33,5 & 28,4 & 16,5 \\
\hline Non Acropora & 17,0 & 36,4 & 27,8 & 14,4 & 35,0 & 33,6 \\
\hline Biota lain & 15,2 & 27,4 & 23,6 & 26,7 & 17,3 & 27,4 \\
\hline Abiotik & 40,4 & 19,8 & 13,4 & 12,3 & 11,1 & 18,0 \\
\hline Dead Coral & 27,0 & 15,0 & 10,0 & 03,0 & 08,0 & 05,0 \\
\hline
\end{tabular}

Berdasarkan data Tabel 6. Dapat di ketahui bahwa Acropora terdapat pada seluruh stasiun dan persentase tutupan yang paling banyak pada setiap stasiun pada kedalam 3 meter mulai ST-1 sampai dengan ST-6 adalah sebagi

berikut: Dead coral (ST-1), Biota lain (ST-2), Non-Acropora (ST-3), NonAcropora (ST-4), Dead coral (ST-5), dan Acropora (ST-6). Berdasarkan data Tabel 6 dapat dibuat grafik seperti Gambar 2

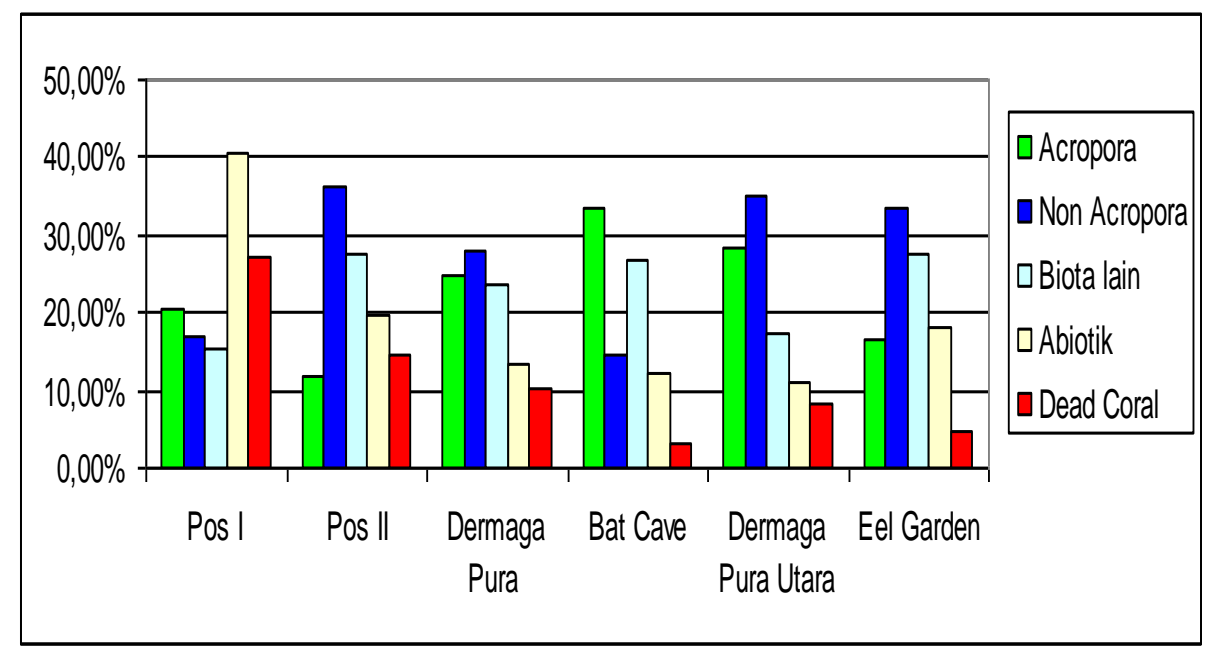

Gambar 2 Presentase Tutupan Karang Pada kedalaman 3 Meter

Dari Tabel 7. dapat diketahui tutupan karang paling banyak pada setiap stasiun adalah sebagai berikut: Abiotik (ST-1), Non-Acropora (ST-2), Non-Acropora (ST-3), Biota lain (ST-4),
Non Acropora (ST-5), Non Acropora (ST-6). Presentase tutupan karang pada kedalaman 10 meter dapat dibuat grafik seperti Gambar 3. 


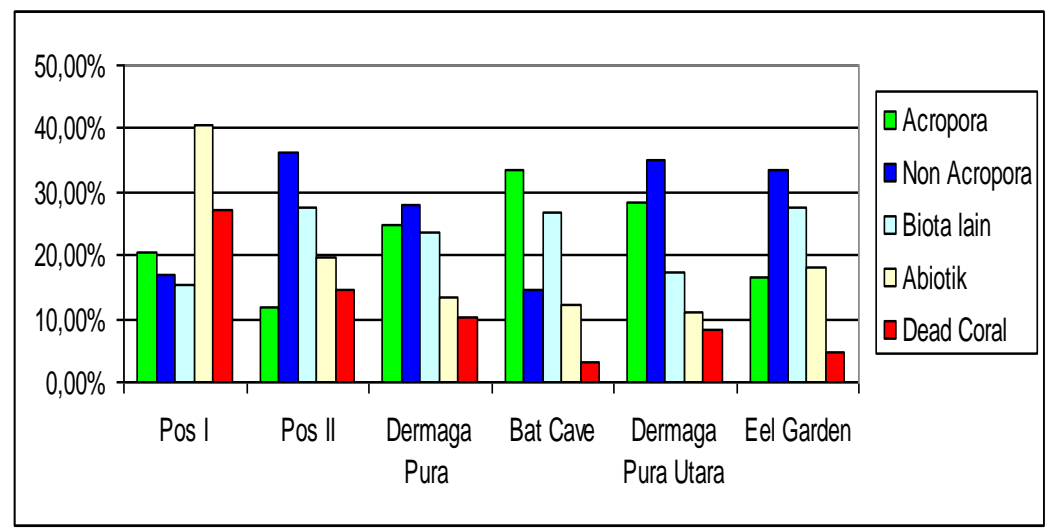

Gambar 3 Presentase Tutupan Karang Pada Kedalaman 10 Meter

Berdasarkan data yang diperoleh dapat diinterpretasikan bahwa secara umum dapat dikatakan terumbu karang di ST-1 memiliki kondisi sedang, yaitu sebesar $31.70 \%$. Kondisi lingkungan seperti ini dimungkinkan untuk direkomendasikan sebagai tempat introduksi dive dan uji lapangan selam. Lokasi pada ST-1 terlindung dari arus kencang dan gelombang besar, sehingga relatif aman serta memiliki paparan pasir yang cukup luas terutama di sebelah barat dermaga, sehingga pengrusakan terumbu, terutama karena kurangnya penguasaan daya apung dapat dihindari.

Kondisi terumbu karang pada ST-2 tergolong dalam kategori sedang, yaitu $49.23 \%$ dari kedua kedalaman yang diteliti. Kondisi ini dapat disebabkan karena ST-2 memiliki gelombang yang relatif tenang dan terlindung dari arus kencang, sehingga relatif lebih aman. Lokasi ST-2 sangat baik diperuntukkan untuk kegiatan snorkeling, mengingat lebar hamparan karang datar lebih dari 100 meter dengan kedalaman kurang dari 5 meter serta tingkat kecerahannya sangat tinggi. Kondisi karang yang baik berada agak jauh dari dermaga. Hal ini disebabkan karena banyak kapal boat yang bersandar pada dermaga.

Kondisi terumbu karang pada ST-3 (di Dermaga Pura) tergolong dalam kategori sedang yaitu $48.67 \%$. Kondisi lingkungan di lokasi ini memiliki gelombang dan arus yang cukup kuat, sehingga perlu perhatian yang lebih. Kondisi karang yang baik berada sedikit menjauh dari dermaga. Hal ini dikarenakan banyaknya kapal boat yang bersandar, sehingga banyak karang yang hancur. Ke arah timur dermaga akan dijumpai tebing-tebing karang yang terjal dan keunikan karang disini adalah memiliki profil karang dari berkontur datar dengan kedalaman 3 meter kemudian berubah drastis menuju ke terjal lebih dari 40 meter dengan jarak dari garis pantai sekitar 20 meter, sehingga pada kedalaman tersebut tampak berbagai jenis karang yang menempel seperti dinding rumah.

Kondisi terumbu karang pada ST-4 (di Bat Cave) tergolong dalam kategori baik yaitu $52.48 \%$. Kondisi lingkungan di lokasi ini menyerupai lokasi Dermaga Pura dengan gelombang dan arus yang kuat dengan hamparan tebing-tebing yang curam. Pengaruh arus dan 
morfologi pulau tersebut, maka terdapat beberapa hal yang spesifik, seperti banyaknya karang lunak, Gorgonian, Sponge dan non Acropora (coral Foliose, coral Massive, coral Submassive, dan coral Mushrom) pada rataan terumbu, tubir, dan dinding serta profil dindingnya yang hampir tegak lurus.

Kondisi terumbu karang pada ST-5 (di Dermaga Pura Utara) tergolong dalam kategori sedang yaitu $45.47 \%$. Memiliki gelombang dan arus yang sangat kuat, sehingga kekuatannya dapat merusak beberapa lifeform yang bercabang (brancing), menjari (digitate), dan lembaran (foliose). Kondisi ini dapat dilihat kedalaman 3 meter yang mendapat hempasan gelombang yang terus menerus, karena stasiun ini terletak di daerah yang menghadap angin, sehingga membuat karangkarang yang telah rapuh akibat terkena hama Acanthaster plancii dan mengalami bleaching menjadi rusak dan patah-patah, sehingga banyak ditemukan patahan karang di kedalaman ini. Pengaruh arus dan morfologi pulau tersebut, maka terdapat beberapa hal yang spesifik, seperti banyaknya karang lunak, Gorgonian, Sponge dan non Acropora pada rataan terumbu, tubir, dan dinding serta profil dindingnya yang hampir tegak lurus.

Lokasi pengamatan pada ST-6 diberi nama Eel Garden, karena banyak terdapat eel (belut laut) di dasar perairan. Pada stasiun ini terdapat beberapa vegetasi mangrove. Secara umum dapat dikatakan bahwa terumbu karang di Eel Garden memiliki kondisi yang sedang, yaitu $51 \%$ dari kedua kedalaman yang diteliti. Biota yang banyak dijumpai pada lokasi ini selain eel (belut laut) di dasar perairan juga ditemukan sponge dalam ukuran yang besar, berbagai jenis karang, seperti karang masif, foliose, dan mushroom. Beragamnya biota yang ditemukan di lokasi ini, dapat disebabkan karena gelombang pada ST-6 cukup tenang, sehingga relatif aman. Lebarnya hamparan karang datar lebih dari 100 meter dengan kedalaman kurang dari 5 meter serta tingkat kecerahan yang sangat tinggi, maka sangat sesuai diperuntukkan untuk kegiatan snorkeling. Selain itu, mengingat daerah ini memiliki paparan pasir yang cukup luas terutama di sebelah Barat, maka dapat direkomendasikan untuk tempat introduksi dive dan uji lapangan selam.

Selain kondisi tutupan karang, hasil pengamatan juga menunjukkan bahwa terdapat 18 famili hard coral, yaitu: Acroporidae,

Agariicidae, Astrocoeniidae, Dendrophyliidae, Euphyliidae, Faviidae, Fungidae, Helioporidae, Merulinidae, Milleporidae, Mussidae, Oculinadae, Pectiniidae, Pocilloporidae, Poritidae, Psammocora, Siderastreidae, dan Tubiporidae serta 3 jenis soft coral seperti Sarcophyton sp, Dendronephyta sp, dan Sinularia sp.

Jenis ikan karang yang ditemukan pada umumnya berupa ikan hias dengan jumlah sekitar 52 jenis. Ikan tersebut kebanyakan membentuk schooling fish (kumpulan ikan) dengan warna dan bentuk yang beranekaragam. Beragamnya ikan hias tersebut terdiri dari: 1) ikan target seperti famili Acanthuridae, famili Serranidae dan famili Labridae; 2) ikan indikator dari famili Chaetodontidae dan 3) ikan mayor seperti famili Pomacentridae, famili Scaridae, famili Pomacanthidae, famili 
Aulostomidae, famili Balistidae, famili Ephipidae, famili Holocentridae, famili Nemipteridae, famili Ostraciidae, famili Pinguipedidae, famili Tetraodontidae, dan famili Zanclidae.

Keberadaan ikan di area terumbu karang sangat bergantung pada kondisi terumbu karang itu sendiri. Seperti kelompok ikan indikator (ikan KepeKepe; butterfly fish; famili Chaetodontidae) yang merupakan ikan indikator untuk menilai kesehatan terumbu karang memiliki kelimpahan yang cukup banyak, begitu pula dengan kelompok ikan mayor, seperti Chromis analis, Chromis antripectoralis, Chromis caudalis dan Chromis margaritifer yang cukup banyak dijumpai kehadirannya hampir di setiap stasiun pengamatan.

Masih cukup banyak dijumpainya ikan indikator, yaitu dari famili Chaetodontidae, menandakan kondisi terumbu karang masih cukup baik. Menurut Nybakken (1992) ikan indikator merupakan ikan yang aktif memangsa koloni karang, seperti ikan Kepe-Kepe (Chaetodontidae), ikan Kakak Tua
(Scaridae), ikan Pakal Tato (Balistidae), dan ikan Buntal (Tretaodontidae), begitu juga Myer dan Randall (1983) menyebutkan kehadiran ikan KepeKepe tidak terlepas dari keberadaan terumbu karang, karena ikan ini merupakan salah satu indikator kesehatan karang. Semakin beragamnya spesies ikan dari kelompok ini menandakan tingkat kesehatan karang semakin tinggi. Keanekaragaman spesies ikan yang tinggi juga disebabkan oleh variasi habitat yang ada di ekosistem terumbu karang. Variasi habitat seperti daerah berpasir, berbagai lekuk dan celah, daerah alga, serta perairan yang dangkal atau dalam dapat menambah keragaman tidak hanya ikan tetapi juga biota laut lainnya, seperti berbagai jenis dari mega benthos.

\section{b. Kondisi Kualitas Perairan Pulau Menjangan}

Hasil penelitian terhadap kualitas air di perairan Pulau Menjangan diperoleh data seperti Tabel 8.

Tabel 8 Kondisi Kualitas Perairan Pulau Menjangan

\begin{tabular}{lcccccc}
\hline ST & $\begin{array}{c}\text { Suhu } \\
(\mathrm{o} C)\end{array}$ & $\begin{array}{c}\text { Turb } \\
(\mathrm{NTU})\end{array}$ & $\mathrm{pH}$ & $\begin{array}{c}\text { Sal } \\
(\%)\end{array}$ & $\begin{array}{c}\mathrm{DO} \\
(\mathrm{mg} / \mathrm{l})\end{array}$ & $\begin{array}{c}\mathrm{BOD}_{5} \\
(\mathrm{mg} / \mathrm{l})\end{array}$ \\
\hline 1 & 29 & 0.055 & 7.6 & 28.8 & 7.87 & 0.12 \\
2 & 29 & 0.033 & 7.6 & 28.9 & 8.00 & 0.12 \\
3 & 29 & 0.030 & 7.7 & 28.9 & 7.89 & 0.12 \\
4 & 29 & 0.022 & 7.8 & 29.0 & 7.97 & 0.13 \\
5 & 28 & 0.035 & 7.5 & 29.0 & 7.60 & 0.12 \\
6 & 27 & 0.043 & 7.4 & 28.5 & 8.01 & 0.15 \\
\hline
\end{tabular}

Kriteria penilaian (Kepmen Negara LH No. 51, 2004)

Berdasarkan Tabel 8 di atas dapat diketahui bahwa kualitas air di perairan
Pulau menjangan termasuk baik, karena dari 7 parameter yang diuji, tidak ada 
parameter yang melebihi atau melewati ambang batas baku mutu air laut untuk wisata bahari sesuai Kepmen Negara LH No. 51 tahun 2004. Kondisi kualitas perairan ini tidak terlepas dari keadaan Pulau Menjangan yang tidak berpenduduk, letaknya yang cukup jauh dari mainland (Pulau Bali) dan berada di sekitar laut terbuka, sehingga limbah antropogenik tidak ada. Hal ini bisa dilihat dari parameter konsentrasi Amonia $\left(\mathrm{NH}_{3}\right), \mathrm{BOD}_{5}$ dan Turbiditas yang nilainya sangat rendah. $\mathrm{BOD}_{5}$ mengindikasikan jumlah bahan organik perairan yang mudah diuraikan secara biologis serta jumlah oksigen yang dibutuhkan untuk proses dekomposisi (Widigdo, 2001).

Secara tidak langsung $\mathrm{BOD}_{5}$ merupakan gambaran kadar bahan organik yaitu jumlah oksigen yang dibutuhkan oleh bakteri aerob untuk mengoksidasi bahan organik menjadi karbondioksida dan air (Davis dan Cornwell, 1991 dalam Effendi, 2003). $\mathrm{BOD}_{5}$ merupakan salah satu indikator pencemaran organik pada suatu perairan, dimana perairan yang mempunyai nilai $\mathrm{BOD}_{5}$ tinggi mengindikasikan bahwa perairan tersebut telah tercemar oleh bahan organik. Bahan organik akan diuraikan secara biologis dengan melibatkan bakteri melalui sistem oksidasi aerobik dan anaerobik. Proses oksidasi aerobik akan menyebabkan terjadinya penurunan oksigen terlarut sampai pada tingkat terendah dan mengakibatkan kondisi perairan menjadi anaerob yang berdampak terhadap kematian organisme. Menurut Lee \& Arega (2000), tingkat pencemaran suatu perairan dapat dilihat berdasarkan nilai $\mathrm{BOD}_{5}$-nya yang terbagi dalam 4 (empat) kategori : (1) Nilai $\mathrm{BOD}_{5}<2.9 \mathrm{mg} / \mathrm{l}$ termasuk kategori tidak tercemar; (2) nilai $\mathrm{BOD}_{5}$ antara $3.0-5.0 \mathrm{mg} / \mathrm{l}$ termasuk kategori tercemar ringan; (3) nilai $\mathrm{BOD}_{5}$ antara 5.1 - $14.9 \mathrm{mg} / \mathrm{l}$ termasuk kategori tercemar sedang; dan (4) nilai $\mathrm{BOD}_{5}>15 \mathrm{mg} / \mathrm{l}$ termasuk kategori tercemar berat. Berdasarkan hal ini, maka perairan Pulau Menjangan masuk kategori belum tercemar.

\section{Kesesuaian Ekowisata Bahari}

Berdasarkan hasil pengamatan dan penilaian kondisi biofisik lingkungan kawasan Pulau Menjangan untuk ekowisata selam diperoleh data seperti Tabel 9.

Tabel 9. Hasil Penilaian Kesesuaian Lahan untuk Ekowisata Selam

\begin{tabular}{|l|c|c|c|c|}
\hline \multicolumn{1}{|c|}{ Parameter } & Kriteria & Bobot & Skor & $\Sigma$ \\
\hline Kecerahan perairan (\%) & 100 & 3 & 3 & 9 \\
Tutupan komunitas karang (\%) & $25-50$ & 3 & 1 & 3 \\
Jenis life form (sp) & $>12$ & 2 & 3 & 6 \\
Jenis ikan karang (sp) & $20-<50$ & 2 & 1 & 2 \\
Kedalaman terumbu karang (m) & $6-15$ & 2 & 2 & 4 \\
Kecepatan arus (cm/det) & $>15-30$ & 1 & 3 & 3 \\
\hline \multicolumn{2}{|r|}{ Total } \\
\hline
\end{tabular}

Dari hasil penilaian dapat diketahui bahwa nilai indeks kesesuaian wisata selam di Pulau Menjangan adalah sebesar 69,2 atau dengan kategori S2 (cukup sesuai). Nilai kesesuaian dan kategori yang didapatkan menunjukkan 
bahwa terumbu karang di Pulau Menjangan masih layak untuk digunakan kegiatan wisata selam. Stasiun pengamatan yang direferensikan untuk aktivitas ini adalah Dermaga Pura, Bat Cave, Dermaga Pura Utara dan Eel Garden. Indeks kesesuai masih dapat di tingkatkan, misalnya dengan melakukan transplantasi trumbu karang.

Hasil penilaian menunnjukan bahwa kecerahan perairan mendapatkan skor 3 yang airnya jernih. Kecerahan merupakan syarat utama yang harus dipenuhi dalam kegiatan wisata selam dan snorkeling. Semakin cerah suatu perairan, keindahan taman laut yang dapat dinikmati wisatawan juga akan semakin tinggi. Perairan yang jernih memudahkan wisatawan untuk melihat dan mempelajari keindahan trumbu karang. Persentase penutupan komunitas karang, jenis life form, dan jenis ikan karang juga menjadi hal penting karena merupakan daya tarik tersendiri bagi wisatawan. Variasi morfologi karang beserta beragamnya warna menjadi faktor penentu keindahan taman laut tersebut.

Hasil penilaian kesesuaian lahan untuk ekowisata snorkeling diperoleh data seperti Tabel 10 berikut

Tabel 10 Hasil Penilaian Kesesuaian Lahan untuk Ekowisata Snorkeling

\begin{tabular}{|l|c|c|c|c|}
\hline \multicolumn{1}{|c|}{ Parameter } & Kriteria & Bobot & Skor & $\Sigma$ \\
\hline Kecerahan perairan (\%) & 100 & 3 & 3 & 9 \\
Tutupan komunitas karang (\%) & $25-50$ & 3 & 1 & 3 \\
Jenis life form (sp) & $>12$ & 2 & 3 & 6 \\
Jenis ikan karang (sp) & $>50$ & 2 & 3 & 6 \\
Kedalaman terumbu karang (m) & $1-3$ & 2 & 3 & 6 \\
Lebar hamparan datar karang (m) & $>100-500$ & 2 & 3 & 6 \\
Kecepatan arus (cm/det) & $0-15$ & 1 & 2 & 2 \\
\hline \multicolumn{4}{|c|}{ Total } \\
\cline { 1 - 2 }
\end{tabular}

Dari Tabel 10 dapat diketahui bahwa nilai indeks kesesuaian wisata snorkeling di Pulau Menjangan adalah sebesar 84.4 dengan kategori S1 (sangat sesuai). Nilai atau kategori yang didapatkan ini, tentunya dipengaruhi oleh kondisi nyata di lapangan. Dimana kelebihan pesisir Pulau Menjangan adalah memiliki hamparan karang datar yang cukup lebar (>100 m) di beberapa titik, dengan kondisi perairan yang sangat cerah (bening) dan kedalamannya rata-rata 3 meter dengan kecepatan arus $<5 \mathrm{~cm} / \mathrm{dt}$, sehingga memang sangat cocok untuk aktivitas snorkeling.
Stasiun pengamatan yang direferensikan untuk aktivitas ini adalah ST-1 (Pos I), ST-2 (Pos II), ST-3 (Dermaga Pura), dan ST-6 (Eel Garden), namun tentunya potensi dan kondisi ini harus tetap terjaga kelestariannya, sehingga perlu pengaturan yang baik mengenai jumlah wisatawan yang dapat ditampung dan peranan pemandu wisata dalam menjelaskan kondisi lapangan dan melaksanakan peraturan yang telah ditetapkan. 


\section{Daya Dukung Ekologi Ekowisata Bahari}

Berdasarkan hasil perhitungan didapatkan bahwa daya dukung kawasan Pulau Menjangan yang dimanfaatkan untuk kegiatan ekowisata dapat dilihat pada Tabel 11.

Tabel 11 Penilaian daya dukung pemanfaatan untuk ekowisata bahari Kegiatan

Daya Dukung Pemanfaatan (org/hari)

\begin{tabular}{cc}
\hline Diving & 28 \\
Snorkeling & 24 \\
\hline
\end{tabular}

Dari Tabel 11 dapat diketahui bahwa daya dukung Pulau Menjangan untuk pemanfaatan ekowisata bahari dengan kategori wisata diving (selam) sebanyak 28 orang per hari dan wisata snorkeling sebanyak 24 orang per hari. Besarnya daya dukung masing-masing stasiun pengamatan dalam satu hari untuk wisata selam adalah ST-1 (2 orang), ST-2 (2 orang), ST-3 (4 orang), ST-4 (8 orang), ST-5 (5 orang), dan ST6 (7 orang). Untuk wisata snorkeling adalah ST-1(4 orang), ST-2 (4 orang), ST-3 (5 orang), ST-4 (2 orang), ST-5 (2 orang), dan ST-6 (7 orang). Nilai daya dukung pemanfaatan yang diperoleh untuk setiap aktivitas wisata ini kemudian diukur dalam setahun maka nilai daya dukung pemanfaatannya akan menjadi 10.080 orang per tahun untuk wisata selam dan 8.640 orang per tahun.

Apabila mengacu pendapat Scura dan Van't Hof (dalam Davis dan Tisdell, 1995), bahwa daya dukung ekologis untuk wisata selam dan snorkeling pada suatu kawasan konservasi adalah sekitar 200000 orang penyelam per tahun (300 hari). Dibandingkan dengan hasil analisis daya dukung di atas, maka kegiatan ekowisata di kawasan Pulau Menjangan masih memenuhi syarat. Hawkins dan
Roberts (1997) merekomendasikan angka $5.000-6.000$ penyelam per satuan lokasi dalam satu kawasan per tahun dapat digunakan untuk menduga daya dukung kawasan konservasi laut yang bergantung dari jumlah lokasi penyelaman yang dapat digunakan, sedangkan Dixon et al. (1993) menyarankan batasan $4.000-6.000$ penyelam per tahun. Diasumsikan 300 hari per tahun penyelaman pada lokasi tertentu, angka yang direkomendasikan dari Dixon et al. (1993), (Schleyer dan Tomalin, 2000) dan Hawkins dan Roberts (1997) menyetarakan 13 sampai 20 orang penyelam per lokasi selam per hari.

Pembatasan jumlah wisatawan sesuai daya dukung kawasan bertujuan agar sumber daya alam dan lingkungan di kawasan tersebut secara alami dapat berasimilasi, sehingga aktivitas kegiatan ekowisata tidak menimbulkan dampak negatif terhadap sumber daya alam dan lingkungan di kawasan tersebut. Hal ini sesuai dengan syarat destinasi ekowisata

Untuk itu, beberapa hal yang dapat dilakukan untuk menjaga dan meningkatkan kondisi sumber daya alam seperti meningkatkan aktifitas pengawasan lingkungan seperti monitoring kondisi ekosistem secara 
berkala, adanya pembagian jumlah pengunjung dan waktu kunjungan secara proporsional untuk tiap dive spot dan mengadakan kegiatan rehabilitasi seperti melakukan transplantasi trumbu karang atau membentuk suatu daerah perlindungan laut di lokasi yang dianggap perlu pemulihan kondisi.

\section{KESIMPULAN DAN SARAN}

\section{Kesimpulan}

Berdasarkan hasil analisis data penelitian dapat dibuat beberapa kesimpulan seperti berikut.

1. Perairan Pulau Menjangan memiliki kondisi yang baik untuk dapat dikembangkan menjadi destinasi ekowisata bahari karena memuliki ekosistem trumbu karang yang sangat indah dengan adanya beragam ikan karang dan biota lainnya.

2. Kondisi biofisik perairan Pulau Menjangan memenuhi syarat untuk dikembangkan kegiatan diving (selam) dan snorkeling.

3. Untuk keberlajutan ekowisata bahari di Pulau Menjangan dapat dikembangan kan Model Ekowisata Bahari Berbasis Pendidikan Terpadu (EBBPT). Edukasi tentang pentingnya konservasi perlu diberikan kepada seluruh yang terlibat dalam pariwisata dan dikembangkan atraksi wisata edukatif seperti menggidentifikasi trumbu karang dan atraksi wisata konservasi dengan melakukan trasplantasi karang.

4. Daya dukung kawasan Pulau Menjangan yang dapat dimanfaatkan untuk kegiatan diving adalah 28 orang per hari dan untuk snorkeling 24 orang per hari.

5. Untuk mendukung aktivitas wisata edukatif pada ekowisata bahari perlu dikembangakan buklet panduan identifikasi trumbu karang dan untuk wisata konsevasi dikembangan buklet panduan melakukan transpalntasi terumbu karang.

\section{Saran}

Berdasarkan hasil penelitian dapat dibuat beberapa saran seperti berikut.

1. Perlu dikembangkan model ekowisata bahari berbasis pendidikan dan konservasi untuk menjamin keberlajutannya.

2. Perlu dikembangan jenis atraksi wisata yang baru seperti melakukan diving atau snorkeling sambil belajar tentang jenis-jenis terumbu karang dan belajar melakukan transplantasi terumbu karang.

3. Perlu mengoptimalkan peran pemerintah dan masyarakat untuk ikut menjaga kelestarian lingkungan.

\section{DAFTAR PUSTAKA}

Baiquni, M. 2010. Pariwisata dan Krisis Lingkungan Global. Dalam: Anom, dkk. Pariwisata Berkelanjutan dalam Pusaran Krisis Global. Denapasar: Udayana University Press.

Bernett Thorne Cultural Tourism. 2009. The Eco-Tourism Model, available at:

http://www.bernetthorneculturaltouri sm. Acessed 
BPS. 2011. Buleleng Dalam Angka. Badan Pusat Statistik Kabupaten Buleleng.

Butler R. 2002. Implementing Sustainable Tourism Development on a Small Island: Development and Use of Sustainable Tourism Development Indicators in Samoa. Journal of Sustainable Tourism 10(5):363-387.

Cater E, Lowman M. 1994. Eco-tourism: A Sustainable Option. Whiley. London.

Ceballos V, Lascurain H. 1996. Tourism, Ecotourism, and Protected Areas. World conservation Union. Gland. Switzerland.

deVantier L, Turak E. 2004. Managing Marine Tourism in Bunaken National Park and Adjacent Waters. Technical Report was preprared by The Natural Resources Management (NRM III) Program's Protected Areas and Agriculture Team. North Sulawesi. Indonesia.

Direktorat Jenderal Departemen Pariwisata, Seni dan Budaya,1999. Garis besar pedoman pengembangan ekowisata Indonesia, tersedia pada http://www.ekowisata.info, diakses hari Kamis, 12 April 2012.

DJPKKH. 2001. Kriteria Ekowisata. Jakarta: Badan Pengendalian Dampak Lingkungan Kemetrian Lingkungan Hidup.

DJPPK. 2003.2 Pedoman Pengembangan Wisata Bahari Berbasis Masyarakat di Kawasan Konservasi Laut. Jakarta:
Departemen Kelautan dan Perikanan.

Dowling RK. 1995. Ecotourism, Concept, Design, and Strategy. Tourism Recreation Research. 20 pp 60-65.

Dowling RK. 1997. Ecotourism in Southeast Asia. Tourism Management Journal. Vol. 18 No. 1 pp 51-57.

Dymond SC. 1997. Indicators of Sustainable Tourism in New Zealand: A Local Government Perspective. Journal of Sustainable Tourism 5 (4): 279-292.

English S, Wilkinson C, Baker V. 1994. Survey Manual for Tropical Marine Resource. Townsville: Australian Institute of Marine Science.

Eriyatno. 1999. IImu Sistem: Meningkatkan Mutu dan Efektivitas Manajemen. IPB Press. Bogor

Fandeli C. M. 2000. Pengusahaan Ekowisata. Fakultas Kehutanan Universitas Gadjah Mada. Yogyakarta.

Garraway J, Nelson H, James C. 1998. Ecotourism as a Strategy for Sustainable Development: The Asa Wright Centre Trinidad and Tobaco. Small Island Developing States Vol 2: 93-111.

Halpenny, E. 2002. Marine Ecotourism: Impact, International Guidelines and Best Practices, Case Study. Burlington: The International Ecotourism Spciety.

Hutabarat A, Yulianda $F$, Fahrudin A, Harteti S, Kusharjani. 2009. Pengelolaan Pesisir dan Laut 
Secara Terpadu (Edisi I). Pusdiklat Kehutanan. Deptan. SECENKOREA International Coorperation Agency.

Mahdayani, Masberg BA, Morales N. 1999. A Case Analysis of Stategies in Ecotourism Development. Aquatic Ecosystem Health and Management Journal. Vol 2:289300.

Mehmet P, Turker MF. 2006. Estimation of Recreational Use Value of Forest Resources by Using Individual Travel Cost Method and Contingent Valuation Method. Journal of Applied Sciences, Vol. 6: 1-5.

META. 2002. Planning for Marine Ecotourism in the UE Atlantic Area. Univ. of The West England. Bristol.

Nurisyah S, Pramukanto Q, Wibowo, S. 2003. Daya Dukung Dalam Perencanaan Tapak. Bahan kuliah Analisis dan Perencanaan Tapak. PS Arsitektur Lanskap. Fakultar Pertanian. IPB-Bogor.

Orams, M.B. 2002 Int. J. Sustainable Develompment, 5(3):338 -352

Plomp, Tjeerd. 2010. Educational Design Research: an Introduction. In Tjeerd Plomp and Nienke Nieveen (Ed). An Introduction to Educational Design Research (hlm.
9-36) Netherlands: Netzodruk, Enschede an

Selin S. 1999. Developing a Typology of Sustainable Tourism Partnership. Journal of Sustainable Tourism. Vol.7(4):260-273.

Selin S. 1999. Developing a Typology of Sustainable Tourism Partnership. Journal of Sustainable Tourism. Vol.7(4):260-273.

Simon F, Yeamduan N, Daniel P. 2004. Carrying Capacity in The Tourism Industry: $A$ Case Study of Hengistbury Head. Tourism Management Journal vol 25. PP. 275-283. Pergamon.

Wood, E.M., 1999. Succesful Ecotourism Business. The Right Approach. World Ecotourism Conference. Kota Kinabalu. Sabah.

Wood, M. E. 2002. Developing a Framework to Evaluate Ecotourism as a Conservation and Sustainable Development Tool. TIES.

Wood, M.E. 2002. Ecotorism: Principles, Practice, and Policies for Sustainability. New York: United Nation Publication.

Yudasmara A. 2010. Model Pengelolaan Ekowisata Bahari di Kawasan Pulau Menjangan Bali Barat. Disertasi. Ps. Pengelolaan Sumberdaya Pesisir dan Lautan. IPB. 